\title{
Atlantic Ocean science diplomacy in action: the pole-to-pole All Atlantic Ocean Research Alliance
}

Andrei Polejack (10 ${ }^{1,2 凶}$, Sigi Gruber ${ }^{3} \&$ Mary S. Wisz ${ }^{1}$

The ocean provides important ecosystem services to society, but its health is in crisis due to the impacts of human activities. Ocean sustainability requires ambitious levels of scientific evidence to support governance and management of human activities that impact the ocean. However, due to the size, complexity and connectivity of the ocean, monitoring and data collection presupposes high investments, and nations need to cooperate to deliver the ambitious, costly science that is required to inform decisions. Here, we highlight the role that ocean science diplomacy plays in facilitating the science needed to support ocean governance and management from domestic, regional to international scales in the Atlantic region via the All Atlantic Ocean Research Alliance. This Alliance is supported by the Galway Statement (2013), the South-South Framework for Scientific and Technical Cooperation in the South and Tropical Atlantic and the Southern Oceans (2017), and the Belém Statement (2017). We discuss the national and international interests that drove the processes of negotiating these agreements, as well as their challenges to date. We also discuss the potential future of the All Atlantic Alliance, as well as its significance in emerging global initiatives such as the UN Decade of Ocean Science for Sustainable Development (2021-2030).

\footnotetext{
${ }^{1}$ Sasakawa Global Ocean Institute, World Maritime University, Malmo, Sweden. ${ }^{2}$ Ministry of Science, Technology and Innovation, Brasilia, Brazil. ${ }^{3}$ European Commission Retired Official, Brussels, Belgium. ${ }^{凶}$ email: andrei.polejack@gmail.com
} 


\section{Introduction}

he ocean is essential to human life. It regulates our climate by storing carbon and heat (Cheng et al., 2020), produces half of our oxygen (Körtzinger et al., 2004), provides food for billions of people (Food and Agriculture Organization of the United Nations, 2020), as well as alternative sources of energy (Pelc and Fujita, 2002). The ocean lays mineral resources (Cuyvers et al., 2018) and hosts a rich, and yet unknown biodiversity, which holds the potential for the development of new materials, medicines and other products (Halvorson and Quezada, 2009). Nearly $40 \%$ of the global population lives within $100 \mathrm{~km}$ of a coastline (Small and Nicholls, 2003), and for many, the ocean is a workplace supporting fishing, transport, shipping, and tourism.

The ocean is, however, under threat from human activities. Examples of these threats range from climate change, overfishing and destructive fishing, marine pollution, ocean acidification, under water noise, habitat degradation/loss, invasive species, eutrophication, and the cumulative impact of these and many other pressures (Halpern et al., 2008; Rockström et al., 2009). Human activities have changed the ocean, undermined its health and impaired its capacity to deliver benefits to humanity (Lubchenco and Petes, 2010). For these reasons, the ocean has been recognized as a global commons: it is in humanity's best interest to maintain a healthy and sustainable ocean for future generations (Vogler, 2012).

Human activities must be managed and governed in order to maintain ocean health, resilience and function so that it will continue to safely deliver benefits to humankind (Lubchenco and Gaines, 2019). Such management and governance requires ambitious levels of scientific evidence to inform decision making (Stenseth et al., 2020; Visbeck, 2018). Science is needed to understand the way the ocean functions and to predict the state of the ocean. It is also needed to inform decisions about how to plan and regulate human activities that impact the ocean. It is also needed to establish safety and warning systems and to help society to respond and adapt to a changing environment and climate (Bax et al., 2018; Duarte et al., 2020).

Ocean science requires high technological capacity, equipment, and data sharing in order to investigate the complexities of the globally connected ocean (deYoung et al., 2019). Ocean observations and monitoring apply a multiplicity of research platforms, ranging from moored and drifting buoys to satellite imagery, often governed by intergovernmental coordinating mechanisms (Tanhua et al., 2019; Todd et al., 2019). Science at this scale is very costly, and must be coordinated over wide regions in space and time (Miloslavich et al., 2018). Such coordination of efforts and co-investment between Nations can be facilitated through science diplomacy, i.e., the intersection between science and international relations (Wagner, 2002).

Although science diplomacy is not a new practice (for a historical perspective, see Turekian, 2018; Turekian et al., 2015), the concept is relatively new and still debated (Flink and Rüffin, 2019; Ruffini, 2020). The taxonomy provided by The Royal Society \& AAAS (2010) frames this intersection as science in diplomacy, i.e., scientific evidence feeding diplomatic decision making; diplomacy for science, where diplomatic mechanisms facilitate research and development; and science for diplomacy, where countries build a dialog by establishing joint research endeavors.

The ocean international regime has been centered on ocean science (Robinson, 2020). Nevertheless, ocean science diplomacy has largely been overlooked in marine science and ocean policy academic literature. To highlight the important role that ocean science diplomacy has on scientific collaboration and international agreements, this paper examines the case of ocean science diplomacy in the Atlantic. The Atlantic offers a very interesting example of ocean sciece diplomacy for a number of reasons. First, the Atlantic is rich in ecosystem services, and challenged by a diversity of threats (Inniss et al., 2017). Second, The Atlantic is bordered by a wide diversity of nations. These countries differ significantly in culture, politics, wealth, and scientific capacity, and must collaborate to deliver basin-scale ocean science (Brunelle, 2013). Third, several international agreements have emerged to promote science diplomacy in the Atlantic region and have given rise to rapidly expanding scientific collaboration between nations.

In this paper, we will describe the All Atlantic Ocean Research Alliance (the Alliance) as science diplomacy in action. First, we present an overview on the Atlantic Ocean research landscape. Second, we describe the three specific international science and technology instruments that support the Alliance: the Galway Statement (2013), the South-South Framework for Scientific and Technical Cooperation in the South and Tropical Atlantic and the Southern Oceans (2017) and the Belém Statement (2017). Third, we analyze the political and scientific motivations for the adoption of the Alliance. Finally, we discuss the results achieved and potential future outcomes of this ocean science diplomacy endeavor.

\section{International relations to support ocean science collaboration in the Atlantic Region}

The Atlantic Ocean Research landscape. Atlantic ocean research is concentrated in higher latitudes (Inniss et al., 2017). Research capacities, both in terms of marine research infrastructure as in human capital, are concentrated in Northern countries (IOCUNESCO, 2017), as is the majority of the research fleet (Nieuwejaar et al., 2019). UNESCO's Intergovernmental Oceanographic Commission-IOC dataset on marine experts show that the absolute number of researchers auto-declared as Atlantic experts is similar between the South (731 researches) and the North (807 researchers) (IOC-UNESCO, 2017). Most of the publications in marine science, however, come from North America and Europe with a focus on the North Atlantic (as per the assessment from 1996 to 2013 presented in Inniss et al., 2017). Consequently, the South Atlantic, the region between the Equator and the Southern Ocean at $60^{\circ} \mathrm{S}$, is one of the least known, under mapped and under sampled ocean spaces on Earth (Miloslavich et al., 2011).

Knowledge gaps undermine the potential for societies to properly understand and manage ecosystem services that impact countries throughout the Atlantic (Duchez et al., 2016; Lopez et al., 2016). Countries in the Atlantic seek to intensify research on the interconnections and dynamics between South and North Atlantic, by which southern countries' research capabilities are enhanced through the access to ocean research infrastructure, human capacities and funding. Over the years, Atlantic-wide scientific institutions have demonstrated an interest to cross disciplines and establish cooperative ties between South and North Atlantic (Mackenzie et al., 2019; Schmidt et al., 2019). Such cooperative ties require international alliances to define priorities, investments, and desired outcomes, such as policy-relevant knowledge to be applied to a better management of the Atlantic (deYoung et al., 2019). Consequently, diplomatic negotiations were commended to strengthen ocean science in the Atlantic.

\section{The backdrop for the establishment of the Alliance}

The need for cooperation between nations on ocean research in the Atlantic basin created an opportunity for the practice of ocean science diplomacy. The All Atlantic Ocean Research Alliance is the result of a stepwise diplomatic negotiation process with the goal of producing knowledge-based solutions for an improved 
management of the Atlantic Ocean. The Alliance results from a science diplomacy effort that bridged countries, aligning research capacities, sharing costs and co-developing knowledge for societal benefit. The European Commission triggered the negotiation process in 2013 involving first the US and Canada, followed by Brazil, South Africa, Argentina and Cape Verde to implement the internationalization of the European Atlantic Strategy (Fig. 1).

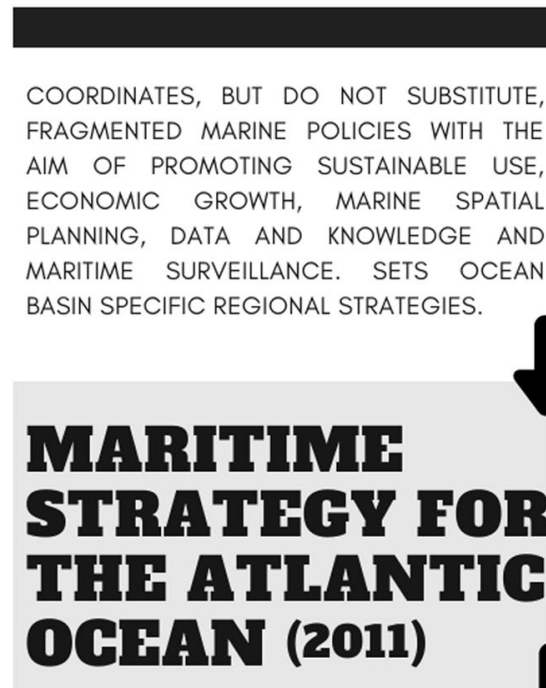

PU'S

INTEGRATHD MARITLME POLIGY (2007)

THE ATLANTIC SEA BASIN STRATEGY WITH THE GOAL OF IMPLEMENTING THE ECOSYSTEM APPROACH, REDUCING EUROPE'S CARBON FOOTPRINT, SUSTAINABLE EXPLORATION OF THE NATURAL RESOURCES ON THE SEA FLOOR AND RESPONDING TO THREATS AND EMERGENCIES

SETS OUT PRIORITIES FOR RESEARCH AND INVESTMENT TO DRIVE THE 'BLUE ECONOMY' FORWARD IN THE ATLANTIC AREA, WHILE CREATING A FOUNDATION FOR COOPERATION WITH OTHER ATLANTIC NATIONS

\section{ATLANTIG AGTION PLANS (2013 \& 2020)}

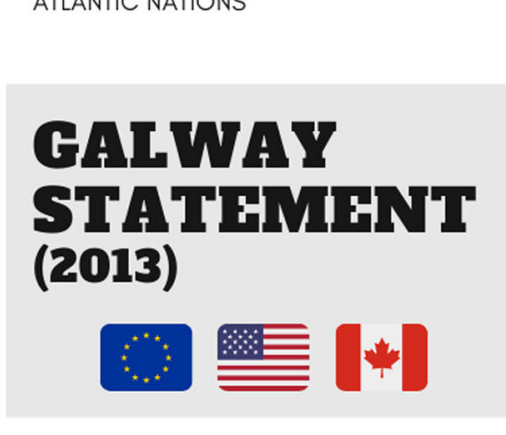

ALSO AN OUTCOME OF THE INTERNATIONALISATION OF THE ATLANTIC STRATEGY, BUT NOW IN ALIGNINMENT WITH A SOUTH -SOUTH FRAMEWORK AND FOCUSED ON THE ALL ATLANTIC, FROM ANTARCTICA TO THE ARCTIC
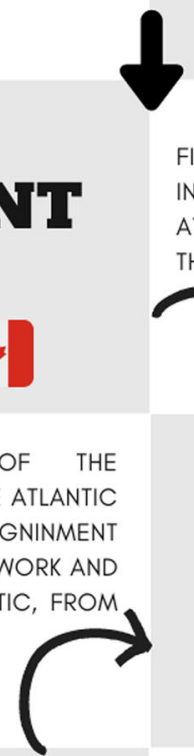

FIRST OUTCOME INTERNATIONALISATION ATLANTIC STRATEGY FOCUSED ON THE NORTH ATLANTIC AND THE ARCTIC

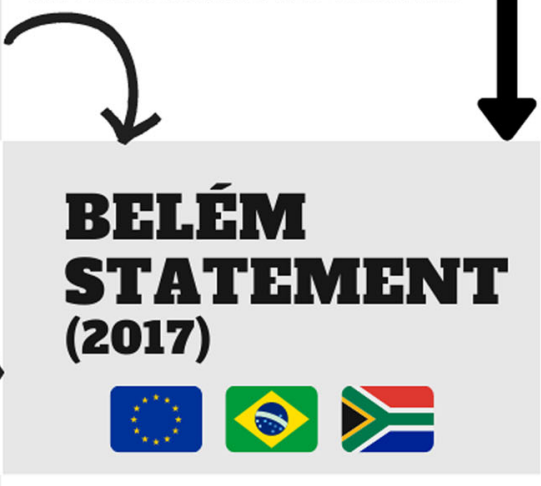

SOUTH-SOUTH FRAMFWORK (2017)

A SOUTH ATLANTIC PROCESS MIRRORING THE GALWAY STATEMENT NEGOTIATIONS. ALTHOUGH NOT SUBJECT TO EU POLICIES, RECEIVED GREAT INFLUENCE OF THE EUROPEAN COMMISSION IN ITS NEGOTIATION 
The European Union's Integrated Maritime Policy coordinates fragmented marine policies at the EU level and establishes sea basin specific strategies that oversee cooperation with third countries (European Commission, 2007). The Atlantic Maritime Strategy (European Commission, 2011a) and its subsequent action plans (European Commission, 2013, 2020) are the implementing arm of the Integrated Maritime Policy for the Atlantic. This Atlantic Strategy is relevant because it gives the mandate to the Commission to reach out for partners in the Atlantic Ocean for further collaboration. Part of the success of the EU's Atlantic Strategy depends on international cooperation.

The first step in implementing the internationalization of the Atlantic Strategy was the Galway Statement. The Galway Statement is a North-North coalition on ocean science and technology signed between Canada, the European Union and the United States of America in 2013. The second step was the South-South Framework. The South-South Framework joined Brazil and South Africa in bilateral ocean science and technology arrangements and was informed by the Commission on the outcomes of the Galway Statement. Finally, South and North were bridged by the signing of the Belém Statement between EU, Brazil and South Africa, setting up an All Atlantic Ocean Research Alliance. The following sections will describe the history and development of these three agreements.

\section{The three international Science and Technology Statements which applied science diplomacy in the Atlantic}

North-North-The Galway Statement. In 2013, the European Union (EU), the United States of America (USA) and Canada started a negotiation process that would trigger a North-centered Atlantic Ocean Research Alliance through an instrument called the Galway Statement on Atlantic Cooperation (hereafter the Galway Statement). The Galway Statement was signed as a result of a large bottom-up consultative process with scientists, government officials and industry (European Union, Canada, and United States of America, 2013). The Galway Statement builds upon the bilateral Science \& Technology agreements between the EU and Canada and between the EU and the USA. The document also highlights the relevance of the EU's Atlantic Maritime Strategy.

The Galway Statement's main purpose is to "(...) increase our knowledge of the Atlantic Ocean and its dynamic systemsincluding interlinks with the portion of the Arctic that borders Atlantic-by aligning our ocean observation efforts to improve ocean health and stewardship and promote the sustainable management of its resources".

The priorities set therein are as follows: i. to align ocean observation efforts; ii. to improve ocean health and stewardship; iii. the sustainable management of the resources; iv. to coordinate data sharing and interoperability; v. seabed and benthic habitat mapping; vi. ocean literacy; vii. researcher mobility; and viii. harness public-private partnerships. By doing so, the expected outcomes were: better ecosystem assessments and forecasts; deeper understanding of vulnerabilities and risk (specially climate related); and new tools to increase resilience, conserve rich biodiversity, manage risk and determine social, environmental and economic priorities (European Union et al., 2013).

A Trilateral Galway Statement Implementation Committee was established in 2013 to oversee the work needed to achieve this Statement's goals. The institutions that lead this Committee are the European Commission's Directorate General on Research \& Innovation, the USA's National Oceanic and Atmospheric Administration and Canada's Department of Fisheries and Oceans.
The European Commission launched a series of calls for proposals in 2014 in support of the implementation of the Galway Statement through the Horizon 2020 Framework Programme for Research and Innovation (European Commission, 2017b, 2019). Proposals involved not only research projects, but also the interesting mechanism of the Coordination and Support Actions -CSA. The CSAs are intended to accompany measures such as standardization, dissemination, awareness-raising and communication, networking, and coordination or support services. CSAs also support policy dialogs and mutual learning exercises/studies, aiding activities of strategic planning, networking and coordination between programs in different countries. As such, CSAs function as support mechanisms for policy, bridging Academia, Government, Civil Society and Industry in and out Europe.

One Coordination and Support Action was funded to support the implementation of the Galway Statement: the Atlantic Ocean Research Alliance Coordination and Support Action, or AORAC$\mathrm{SA}^{1}$. This CSA, due in 2020, was coordinated by the Marine Institute Ireland and involved a consortium spread across key marine organizations in Europe. AORAC-SA overall objectives were to improve the international cooperation framework under the Galway Statement and to create a foundation for the development of large scale joint international marine research programs. AORAC-SA established a High-Level Advisory Board to follow the implementation of the project and make further recommendations and guidance. The High-Level Advisory Board was composed of representatives from the three signatories plus representatives from Brazil and South Africa. AORAC-SA was meant to support the implementation of the Galway Statement and thus lacked research institutions from Brazil and South Africa in the consortium. The participation of Brazil and South Africa in this board was important to exchange relevant information on actions in the South and in the North. The High-Level Advisory Board acted at the CSA level, advising the Trilateral Galway Statement Implementation Committee. This Implementation Committee, composed by the three signatory parties, was responsible to guide, propose and implement concrete actions to the Galway Statement.

The Trilateral Galway Statement Implementation Committee established working groups to operationalize the political commitments taken by the cosignatories of the Galway Statement on specific areas of common interest. These working groups were: Ocean Literacy; Aquaculture; Ecosystem Approach to Ocean Health and Stressors; and Seabed Mapping. The Committee decided not to create a specific group for ocean observations because the AtlantOS project (Optimizing and Enhancing the Integrated Atlantic Ocean Observing Systems), as we will address in detail further, was mandated to coordinate observational systems in the Atlantic. The working group on Seabed Mapping was responsible for coordinating the North Atlantic seafloor mapping. This coordination included ship time and equipment sharing that has proven to be effective (AORA, 2018; Raineault and Flanders, 2019). The findings of the seafloor-mapping working group resulted in a special issue of the research journal Frontiers in Marine Science ${ }^{2}$.

The European Commission first negotiated the terms of the Galway Statement bilaterally, by establishing specific ocean working groups in each of the existing bilateral science and technology agreements with the US and Canada. The Commission used this strategy to establish strong diplomatic and political grounds tied to the bilateral formal agreements. As a consequence, the bilateral working groups resulted immediately into trilateral working groups after the signing of the Galway Statement. The Commission applied similar strategy southwards in the Atlantic, as we will present further. 
South-South: the Framework. In 2013, the same year the Galway Statement was signed, the EU-Brazil Joint Steering Committee on Science and Technology decided to create a Working Group on Ocean Science and Technology. Co-chairs from both the European Commission and the Brazilian Ministry of Science, Technology and Innovations were assigned to coordinate this work. As a result, a bilateral ocean-specific agreement was signed in 2015 (European Union and Brazil, 2015). Similar process occurred in South Africa, with a resulting agreement in 2016 (European Union and South Africa, 2016).

Brazil and South Africa had closely followed the developments under the Galway Statement both because of the bilateral negotiations with the European Commission and their participation in the advisory board of the AORAC-SA. Both Southern countries realized the benefit arising from such a coordination and resolved to develop a similar process in the South Atlantic. As a result, a South-South scientific agenda was crafted for the South Atlantic and Southern Ocean. The initial partners in this discussion included Academics and government officials from Argentina, Namibia, Angola and Uruguay. Brazil and South Africa decided to extend the invitation to the European Commission and European researchers involved in projects in the South Atlantic. The South-South Framework for Scientific and Technical Cooperation in the South and Tropical Atlantic and Southern Oceans was developed after a series of two technical seminars that were financially supported by the European Commission (Brazil and South Africa, 2017). The Framework is centered in the inputs from the South Atlantic community, including the views from those Northern researches who work cooperatively with the South (Claassen et al., 2019).

The South-South Framework is a bilaterally agreed plan for scientific cooperation in oceanic research between South Africa and Brazil. The process of negotiating the Framework included inputs from Argentina, Angola, Namibia, and Uruguay. The final document was adopted only by Brazil and South Africa because internal political processes prevented the other countries to adopt it immediately. Thus, the Framework is open to all countries in the region and is intended to promote scientific cooperation and capacity building among South Atlantic countries. The Framework promotes the exchange of expertize and knowledge of ocean science and technology for the environmental and socioeconomic benefits of countries in the region.

The priorities defined in the South-South Framework include three broad themes that are followed by a more detailed program. The priorities are: i. Climate Variability and Change; ii. Ecosystem Variability and Controlling Processes; and iii. Living and Nonliving resources, and biodiversity. Three cross-cutting areas were identified: human capital development; development and deployment of various platforms for data collection; and collaboration on relevant aspects of big data.

The South-South Framework goes beyond the typical research cooperation to aim also in contributing to the greater economic, political and diplomatic alignment of South Atlantic nations. The document ambitions the development of common and joint imperatives for the South and Tropical Atlantic and the Southern Oceans. The Framework also states the intention to position South Atlantic Ocean countries as global focal points leading joint and individual observational and research endeavors in the South Atlantic.

The will to align the South-South with the Galway Statement can be seen in at least two statements present in the Framework. "Ultimately, it is hoped that the Framework will guide not only South-South, but also South-North scientific cooperation (p. 2)". Also, "(the Framework) is intended to address and build-on current collaborative research programs between Southern countries, and in alignment with Northern countries, with the aim of developing basin scale ocean science and technology development, enhancing human capacity, strengthening ongoing projects, and identifying potential activities and opportunities for further development within this cooperation (p. 9)".

South-North: the Belém Statement. The South-South Framework, through its organization of the Southern nations, was an important pre-requisite toward the development of a basin-scale Atlantic scientific cooperation. Upon the establishment of the South-South Framework, the European Commission, Brazil and South Africa organized a series of seminars to propose a new instrument to establish the All Atlantic Ocean Research Alliance. This instrument is the Belém Statement.

The Belém Statement on Atlantic Research and Innovation Cooperation (European Union, South Africa, and Brazil, 2017) was signed in the Belém Tower of Lisbon in 2017. The Statement main purpose is to improve the collaborative scientific efforts in the Atlantic Ocean and sustainably cooperate on marine science, research and innovation. The Belém Statement highlights the mutual benefit on linking research activities in the South Atlantic and Southern Ocean with those in the North Atlantic. Moreover, the Belém Statement aims to leverage from already existent endeavors, such as the Benguela Current Commission.

The Belém Statement is based on the principles of shared responsibility and mutual benefit. The aims of the Statement are to: promote and facilitate human capital development and scientific exchange; provide a platform and opportunities for scientific and technological cooperation resulting in joint activities; and, encourage new models for cooperation on a coordinated and partnership-based approach to tackle the scientific and societal challenges of the Atlantic Ocean. The Statement connects oceans and climate change, oceans and food, and oceans and energy systems, as well as the dynamics of the Atlantic Ocean and its interconnected circulation systems from Antarctica to the Arctic, representing a pole to pole research effort.

The priority areas set in the Belém Statement are aligned with those decided in the documents forging the North-North and the South-South cooperation (Table 1). The common areas of interest are: 1 . Climate variability and ecosystem approaches; 2. Ocean observation (including seabed mapping), forecasting and monitoring processes and systems; 3 . Food security, fisheries management, aquaculture and biodiversity; 4 . Oceans technology (including for observation and renewable marine energy); 5. The effects of emerging pollutants; and, 6. Polar research (especially interconnections between the Atlantic, the Southern Ocean and Antarctica).

The proposed outcomes of the Belém Statement include: better monitoring and forecasting capacities; improved safety at sea, human health and well-being; sustainable use of marine resources; new and emerging technologies to service societal needs and new value chains; and, ocean-engaged citizens through enhanced ocean literacy activities.

The European Commission allocated funding of approximately 64 million euros in the Horizon 2020 Work Programme to implement the Belém Statement, more precisely under the Blue Growth calls for proposals (European Commission, 2017a). A Coordination and Support Action (CSA) was also funded to support the implementation of the Belém Statement, similar to what was done for the Galway Statement. The All Atlantic Cooperation for Ocean Research and Innovation Coordination and Support Action-AANCHOR CSA aims to support the international cooperation between Europe and South Atlantic countries. AANCHOR also seeks the connection with the different ongoing initiatives and projects in the North Atlantic beyond Europe. 
Table 1 Comparison among the priority areas defined by each of the negotiation processes of the three Atlantic international arrangements on ocean research and development (STI: Science, Technology, and Innovation).

Galway Statement (2013) South-South

Framework (2017)

STI priority areas

Ocean observation (including seabed mapping), forecasting $X$

and monitoring processes and systems

Ocean health, including pollutants

Sustainable management of the resources

Data sharing and interoperability

Seabed and benthic habitat mapping

Ocean Literacy

Climate Variability and Change

Ecosystem Variability and Controlling Processes

Nonliving resources

Biodiversity

Food security, fisheries management \& aquaculture

Oceans technology (including for observation and

renewable marine energy)

Polar research (especially interconnections between the

Atlantic, the Southern Ocean and Antarctica)

Earth system model

Inter-ocean exchanges and large scale circulation

Air-sea exchanges and storage

Paleo evolution

Biological production and biogeochemistry

Continent-Shelf-Ocean continuum

Surface Ocean-Deep Ocean links

Marine biotechnology

Cross-cutting areas

Researcher mobility

Public-private partnerships

Human capital development

Sharing of research infrastructures

$x \quad x$

$x+x$

$x \quad x \quad x$

$x \quad x \quad x$

$x \quad x \quad x$

$x$

$x \quad \begin{array}{ll}x & x \\ x & x\end{array}$

$x$

$x+x$

$X-x$

X $\quad x$

$x$

$x$

$X$

$X$

$x$

$X$

$X$

X $\quad x$

$x-x$

$x \quad x$
AANCHOR differs from its North Atlantic sister project, the AORA-CSA, on including institutions from Latin America and Africa as part of the consortium. A High-Level Board was established to guide AANCHOR. Membership include each of the three signatories plus representatives from the USA, Canada, Argentina and Cape Verde. The High-Level Board in the Belém Statement is similar to the one set up for the Galway Statement in the sense of including partners that are not signatories to the Statement. In fact, Argentina and Cape Verde were included in AANCHOR just after signing bilateral science and technology implementing arrangements for ocean research with the European Commission (European Commission and Argentina, 2018; European Commission and Cabo Verde, 2018). The High-Level Board acts at the CSA level. The implementation of the Belém Statement at a higher political level is done by a trilateral committee composed by the three cosignatories, similar to what was done for the Galway Statement.

AANCHOR assembles experts from around the Atlantic in multi-stakeholder platforms to identify collaborative activities. There are currently five platforms acting as think tanks under AANCHOR. These platforms are: 1. reinforcing capacity building; 2. promoting academia-industry knowledge transfer; 3 . developing common standards (including data); 4. enhancing citizen awareness and ocean literacy; 5 . converging and aligning R\&I infrastructure initiatives. These multi-stakeholder platforms are expected to define long term measures for the cooperation framework of the Belém Statement, beyond the project's lifetime.

Part of the scope of the Belém Statement is about capacity development, particularly for younger generations. The All
Atlantic Ocean Youth Ambassadors program was a response to that objective. The program targets young ocean leaders who are required to promote ocean literacy, outreach and communication strategies. Ambassadors should act both in local community engagement as well as in regional/global communities, advancing their role as early career science diplomats. The first Ambassadors' training happened in 2019 with participants from Argentina, Brazil, Canada, Cape Verde, Europe (several countries), South Africa and the USA (AORA and AANCHOR, 2019b). Recently, the European Commissioner for Innovation, Research, Culture, Education and Youth, Mariya Gabriel officially launched the program ${ }^{3}$ and announced a second round of training, planned for $2021^{4}$.

The Belém Statement implementation is underway with ongoing efforts in research and engagement. As the Belém Statement implementation progresses, interest in the region arises. For example, the European Commission and the Kingdom of Morocco signed in December 2020 an administrative arrangement on marine research and innovation, which highlights the work undergoing in the Belém Statement ${ }^{5}$. Moreover, the African Union has shown interest in the capacity development component. In general, these statements of interests are done at the All Atlantic Forum, an event that has gathered this new Atlantic community to discuss common issues of concern. The Forum happens once a year and have started in Brazil, followed by one edition in Europe and, in 2020, in South Africa ${ }^{6}$. Hopefully, this Alliance will also attract other international initiatives and donors, such as philanthropy, private agents, and NGOs. It will be interesting to follow how impactful this Alliance will be in the future. 


\section{Discussion}

The All Atlantic Ocean Research Alliance as an example of science diplomacy. The process of adopting and creating the All Atlantic Ocean Research Alliance can be framed in the taxonomy proposed by The Royal Society and AAAS (2010). First, it is an example of "science in diplomacy" because scientific advice supported the process of the three above-described international instruments, identifying priority areas and targeted countries. Second, it is an example of "diplomacy for science" since the official documents supporting the Alliance, i.e., bilateral and multilateral agreements, foster research projects and access to infrastructure. Finally, it is an example of "science for diplomacy" because the science-based dialog is bridging countries in the Atlantic around the common goal of societal benefit. This dialog is set in both the existing diplomatic instruments, as well as in the funded research projects.

Science diplomacy addresses goals shaped by (i) national interests and needs; (ii) cross-border interests; and (iii) global needs (Gluckman et al., 2018). The All Atlantic Ocean Research Alliance uses science diplomacy to address goals shaped by similar interests. First, the Alliance was triggered by national interests, in particular the Commission's interests in internationalizing its Atlantic Strategy. Second, the stepwise process of implementing the Alliance covers cross-border interests ranging from North-North and South-South coalitions to a whole basin coordination. Lastly, the aims of the Alliance cover global ocean community interests.

Europe's early role in science diplomacy strategies in the Atlantic. In 2011, the Directorate-General for Research and Innovation of the European Commission, promoted the event "The Atlantic Geopolitical Space: common opportunities and challenges", discussing the Atlantic values to economy and trade, to energy provision and security (European Commission, 2011b). The report of this event highlighted the Atlantic as of major importance to Europe and recommends that alliances are built, by which scientific cooperation should be both a pillar and a facilitator (European Commission, 2011b). The EU's Atlantic Strategy was launched in 2011, stressing scientific cooperation. The Atlantic Strategy offered the political mandate for the European Commission to explore alliances as part of the Strategy's internationalization component. This political context facilitated the signing of the Galway Statement and the bilateral agreements with Brazil and South Africa 2 years later, triggering the process of building up the All Atlantic Ocean Research Alliance. Europe's initiation of a basin-scale ocean science diplomacy endeavor could help to inspire similar initiatives in other basins.

In the All Atlantic Ocean Research Alliance, bilateralism provided the backbone for multilateral science diplomacy. The European Commission used bilateral formal agreements on ocean science and technology with each partner country to progressively build the All Atlantic Ocean Research Alliance. These bilateral agreements included first the US (2012) and Canada (2012), second Brazil (2015) and South Africa (2016) and more recently Argentina (2018), Cape Verde (2018) and the Kingdom of Morocco (2020). This strategy allowed the Commission to establish commitments and compliance from each partnering country when progressing to a multilateral setting. Bilateral science and technology agreements were reported to be useful in promoting science diplomacy (Dolan, 2012).

According to Ruffini (2020), science diplomacy is fueled by national interests. The three science diplomacy instruments in the All Atlantic Ocean Research Alliance support multi-national collaboration on scientific research and potentially also the national interests of the countries involved. For example, the European Commission has been very successful in pushing forward its views, strategies and policies at the international arena, utilizing science diplomacy tools to pursue its goals in the Atlantic (European Union, 2019; López de San Román and Schunz, 2018). European interests in the Atlantic go beyond than acquiring evidence on essential natural assets (European Union, 2020). The Atlantic is an essential part of Europe's Blue Growth agenda to generate jobs and advance industrial development and recovery through ocean and coastal innovation (European Commission, 2013). The Atlantic is also essential to the new European Green Deal in terms of renewable sources of energy and technology developments for food provision and other ocean services (European Commision, 2019).

The Southern interests in the All Atlantic Ocean Research Alliance. Southern Countries, in particular Brazil and South Africa, have had a long running history of scientific cooperation in ocean science that precedes the All Atlantic Ocean Research Alliance.

Since 2005, Brazil and South Africa are both part in the IBAS (India, Brazil, and South Africa) dialog on ocean science (Arkhangelskaya, 2010) and more recently, in 2017, in the BRICS (Brazil, Russia, India, China, and South Africa) working group for ocean and polar sciences ${ }^{7}$. Moreover, Brazil and South Africa have shared an ocean observing system in the South Atlantic since 2010 as a result of the engagement in multilateral ocean science endeavors (Ansorge et al., 2014). These activities allowed ocean science communities from Brazil and South Africa to interact overtime, and to define research priorities and gaps. As a result, researchers from both countries informed the negotiation of the South-South Framework and ultimately the Belém Statement.

By the means of the South-South Framework, Southern nations were able to coordinate their national interests and exercise this power with the North, influencing the Atlantic research agenda and further investments. On the signing event of the Belém Statement, the then Commissioner for Research and Innovation, Carlos Moedas announced a political and financial commitment to promote joint research projects under the implementation of the Belém Statement. This was further promoted and consolidated through the Horizon 2020's Blue Growth calls for research proposals. Proposals in these calls were encouraged to partner with institutions from Brazil and South Africa. This was particularly important for Brazilian researchers because of the current national science budget crisis (Angelo, 2017, 2019; Rodríguez Mega, 2019). Therefore, access to research funding can be seen as national interests to Brazil and South Africa.

The South-South Framework highlights the willingness of Brazil and South Africa to align their national interests and build regional, science-based coalitions aimed at influencing global ocean agendas. The Framework makes explicit reference to the United Nations Convention on the Law of the Sea, the Convention on Biodiversity, the goals of the Food and Agricultural Organization and the International Whaling Commission.

South-South cooperation in this space would address highprofile scientific questions that could provide relevant information to address national priorities as well as lead to opportunities to play an active role in the global sphere (Brazil and South Africa, 2017).

The Alliance's impact in addressing global interests. The Atlantic Ocean is of critical importance to the global ocean and climate dynamics. The All Atlantic Ocean Research Alliance 
contributes to the global ocean knowledge by intensifying research in the Atlantic. One of the main goals of the Alliance is to generate knowledge for social benefit. It is a global community interest to promote an improved ocean governance through the application of the scientific knowledge in decision making (Wisz et al., 2020). The upcoming UN Decade of Ocean Science for Sustainable Development shall be a good opportunity for the All Atlantic Ocean Research Alliance to contribute with research to address global ocean concerns (Claudet et al., 2019).

The Decade of Ocean Science was approved by the UN General Assembly in 2017. UNESCO's Intergovernmental Oceanographic Commission (IOC) was mandated to prepare an implementation plan in consultation with Member States, UN partners and other relevant stakeholders for the 2021-2030 period (United Nations, 2017). IOC has then prepared a Decade's roadmap as an initial guide for the steps and processes needed to develop the requested plan (IOC-UNESCO, 2018; Ryabinin et al., 2019). In this roadmap, international cooperation is urged. Although not explicitly stated, science diplomacy seems essential to implement this Decade.

It is hoped that coordinated region-wide efforts, such as the Belém Statement, will facilitate the implementation of the Decade of Ocean Science. Efforts are currently underway to identify how the Belém Statement's implementation will contribute to the Decade (AORA and AANCHOR, 2019a). In addition, the North Atlantic and South Atlantic Ocean Decade planning workshops were coordinated to align with the work of the All Atlantic Ocean Research Alliance. The Decade of Ocean Science and the Galway and Belém Statements will interact promoting science diplomacy in the Atlantic. It is so far unclear which drivers will guide this interaction, such as governance issues (top-down) or scientifictechnical criteria (bottom-up) or a combination of both.

As the Decade of Ocean Science is intended to support sustainable development, the science must support societal needs. Both the Decade and the All Atlantic Ocean Research Alliance aim to address societal needs by making scientific information relevant, useful and accessible (Ryabinin et al., 2019). The Alliance has put mechanisms in place for public engagement that can be leveraged by the Decade of Ocean Science implementing process. It will be interesting to monitor how countries will incorporate scientific results from the All Atlantic Ocean Research Alliance into their national strategies, which in turn shall support the implementation of the Decade of Ocean Science.

So far, the Alliance is a valuable vehicle to bring people together, work on commonly identified challenges and ensure that results of this cooperation will deliver what coastal communities need in terms of scientific output and translated tools. Thus, there is an added value of ongoing cooperation as a model to inspire others within the wider context of the Decade of Ocean Science.

The future of the All Atlantic Ocean Research Alliance. Some of the Galway projects such as AtlantOS (Optimizing and Enhancing the Integrated Atlantic Ocean Observing Systems) resulted in an important basin-scale coordination of ocean observatories. There is a proposal that AtlantOS continue as a new program connected to IOC's Global Ocean Observing System-GOOS (deYoung et al., 2019). There is a clear link between the new AtlantOS program and the objectives of the Belém Statement, which indicates a future integration towards users' needs and societal benefit (Fritz, 2016). Science diplomacy will be at stage in promoting the means to facilitate research, ranging from national budgets to an international basin-wide collaboration, as well as absorbing the data and results that can feed back into national policies on ocean forecast and monitoring.

A new set of research projects have been funded by the Horizon 2020 Programme in support of the implementation of the Belém Statement and beyond. These research projects will act in large geographical areas, covering the whole Atlantic basin. For example, the Mission Atlantic project aims to conduct integrated ecosystem assessments in the Atlantic basin, a challenge in addressing environmental concerns and commercial activities. Integrated ecosystem assessment is a tool to support the ecosystem-based management by applying an Integrated Ecosystem Approach-IEA (Levin et al., 2009). IEA is the comprehensive integrated management of human activities based on the best available scientific knowledge about the ecosystem, and its dynamics, in order to identify and take action that will support ecosystem health, integrity and sustainability (Smith and Maltby, 2003; UNEP, 2009). A legitimate IEA needs to address different scales (e.g., local, to regional, to basin to global) to better understand the intrinsic relations between different systems (Levin et al., 2009). Ocean science diplomacy can facilitate the work of Mission Atlantic by identifying options to internationally bridge the science needed to support decision making. Mission Atlantic will need to consider the regulatory diversity in the Atlantic and develop practical ways to feed scientific evidence into ocean management in diverse settings. Its IEA framework will help give stakeholders a practical view on how research projects under the All Atlantic Ocean Research Alliance can impact the relations between the countries and provide the relevant knowledge for better decision making.

The new Research and Innovation Program of the European Union, Horizon Europe, will incorporate research and innovation missions to increase the effectiveness of funding by pursuing clearly defined targets (Mazzucato, 2018). One of the five target missions is on healthy oceans, seas, coastal and inland waters. The recently proposed Mission Starfish 2030 establishes several priorities for ocean research that are very much aligned with the All Atlantic Ocean Research Alliance (Lamy et al., 2020). Mission Starfish 2030 also posits international cooperation as part of the desired outcomes and makes explicit reference to the All Atlantic Ocean Research Alliance as an action to be supported.

The All Atlantic Ocean Research Alliance's Youth Ambassadors pilot program has called the attention of different countries, showcasing the Atlantic science diplomacy through ocean literacy and citizen engagement. In only six months of campaigns, the Ambassadors have reached and promoted the Belém and Galway Statements in $>100$ events. It is proving to be effective in promoting the All Atlantic Ocean Research Alliance and in fulfilling Belém's mandate on better engaged citizens. The program should now be broaden to other donors and countries in the region, so the Ambassadors would mainstream ocean science diplomacy throughout the Atlantic.

Finally, there is a potential for the All Atlantic Ocean Research Alliance to serve as a model for other ocean basins. If that shall be the case, ocean science diplomacy practices will have to adapt to different regions' realities and lessons can be learned from the All Atlantic Ocean Research Alliance.

\section{Conclusion}

This article presents a case of ocean science diplomacy in action in establishing an All Atlantic Ocean Research Alliance. The All Atlantic Ocean Research Alliance has emerged from three agreements between different Atlantic bordering countries (the Galway Statement, the South-South Framework, and the Belém Statement). These agreements and the All Atlantic Ocean Research Alliance have triggered EU funding calls, new research projects (e.g., AtlantOs, AANCHOR, and now Mission Atlantic). These projects have bolstered scientific collaboration, scientific exchange and capacity building through the Atlantic in the generation and sharing of new scientific data, knowledge, forecasting and early warning/decision 
support tools. Moreover, the All Atlantic Ocean Research Alliance has already contributed to a diversity of other EU's strategies. Examples include the Blue Growth Strategy, the European Green Deal, and the EU Science, Research and Innovation Policies.

Science informed the diplomatic negotiations of these agreements on priorities and actions needed to provide society with relevant knowledge. Moreover, European Commission played an important role in triggering the negotiation process, motivated by the implementation of the European Union's Atlantic Maritime Strategy, and in particular its international dimension. The process of creating the All Atlantic Ocean Research Alliance resulted in a balance between national/European and ocean community interests. On one hand, we presented European Commission interests in implementing its Atlantic Maritime Strategy. On the other, we discussed the interests of Brazil and South Africa in advancing national gaps in ocean research. The main goal of the All Atlantic Ocean Research Alliance is to develop science to serve global community interests regarding ocean sustainability. Science diplomacy was applied as a tool to balance national interests and broader ocean community interests in the case of the All Atlantic Ocean Research Alliance.

We highlighted the pro-active role that the European Commission played in the Atlantic science diplomacy. The European Commission was very effective at overcoming challenges presented by its multi-level governance, and diverse internal differences within member states (Flink and Schreiterer, 2010; Rüffin, 2020). The Commission based the construction of this Alliance on the existing bilateral agreements with each of the involved countries to support a multilateral alliance. In so doing, ocean science diplomacy was used by the European Commission via the All Atlantic Ocean Research Alliance to achieve political reach in the Atlantic.

The results from the Alliance will both provide scientific evidence in support of national decision making, as well as contribute to international debates on the global ocean environment. The upcoming UN Decade of Ocean Science for Sustainable Development (2021-2030) is an opportunity for the Alliance to inspire the development of global ocean affairs. Through this example, the Alliance can both provide its experience coordinating a basin-wide mechanism between countries for the generation and sharing of ocean science, as well as by making more scientific evidence, tools, and expertize available.

The All Atlantic Ocean Research Alliance bridges countries around common interests, facilitating research and evidencebased dialog that fuels and supports additional international research collaboration. The All Atlantic Ocean Research Alliance exemplifies the need to collectively develop research, human capacity, technology employment and cost sharing mechanisms to better address mutual responsibilities over an ocean basin of utmost importance. A major remaining challenge for this Atlantic Ocean science diplomacy is to ensure the co-creation of policyrelevant science that will support society in the most effective way through an inclusive diversity of disciplines and stakeholders.

\section{Data availability}

No primary data were generated or analyzed for this paper.

Received: 19 June 2020; Accepted: 5 February 2021; Published online: 26 February 2021

\footnotetext{
Notes

1 https://www.atlanticresource.org/aora.

2 The Special Issue can be found at: https://www.frontiersin.org/research-topics/8873/ seafloor-mapping-of-the-atlantic-ocean.

3 https://sway.office.com/8hFw3qpVFwA2o8kD?ref=Link\&loc=play.
}

4 https://allatlanticocean.org/view/news/launch-of-the-selection-process-of-the-newcohort-of-all-atlantic-ocean-youth-ambassadors-

5 https://ec.europa.eu/info/news/commissioner-gabriel-signs-administrativearrangement-marine-research-and-innovation-kingdom-morocco-2020-dec-08_en. 6 https://allatlanticocean.org/view/events/all-atlantic-ocean-research-forum.

7 http://land-ocean.ru/brics/.

\section{References}

Angelo C (2017) Brazilian scientists reeling as federal funds slashed by nearly half. Nature https://doi.org/10.1038/nature.2017.21766

Angelo C (2019) Brazil's government freezes nearly half of its science spending Nature 568(Apr):155-156. https://doi.org/10.1038/d41586-019-01079-9

Ansorge IJ, Baringer MO, Campos EJD, Dong S, Fine RA, Garzoli SL, Van den Berg MA (2014) Basin-wide oceanographic array bridges the south atlantic. Eos Trans Am Geophys Union 95(6):53-54. https://doi.org/10.1002/ 2014EO060001

AORA (2018) Annual report 2018-19. Retrieved from https://www.atlanticresource. org/aora/sites/default/files/GalleryFiles/Publications/AnnualReport2019.pdf

AORA, AANCHOR (2019a) All-atlantic ocean research alliance- communication material. Retrieved 29 Jan 2020, from https://www.allatlanticocean.org/ uploads/ficheiro/ficheiro_5dd5753793d64.pdf

AORA, AANCHOR (2019b) Atlantic Ocean Youth Ambassadors will be inspired to spark change at Summer School. Retrieved 29 Jan, 2020, from https://www. atlanticresource.org/aora/site-area/news-events/press-releases/atlantic-oceanyouth-ambassadors-will-be-inspired-spark-change

Arkhangelskaya AA (2010) India, Brazil and South Africa dialogue forum: a bridge between three continents- challenges, achievements and policy options. Nordic Africa Institute Policy Notes

Bax NJ, Appeltans W, Brainard R, Duffy JE, Dunstan P, Hanich Q, Wilkin J (2018) Linking capacity development to GOOS monitoring networks to achieve sustained ocean observation. Front Mar Sci 5(Sept):346. https://doi.org/ $10.3389 /$ fmars.2018.00346

Brazil, South Africa (2017) South-South framework for scientific and technical cooperation in the South and tropical atlantic and southern oceans. Retrieved from https://www.atlanticresource.org/aora/sites/default/files/GalleryFiles/AtlanticFacts/ South-South-Framework-for-Scientific-and-Technical-Cooperation-in-the-S....pdf

Brunelle D (2013) Comunidades atlánticas: asimetrías y convergencias. Revista CIDOB d'Afers Internacionals 102-103:29-49

Cheng L, Abraham J, Zhu J, Trenberth KE, Fasullo J, Boyer T, Mann ME (2020) Record-setting ocean warmth continued in 2019. Adv Atmos Sci 37:137-142. https://doi.org/10.1007/s00376-020-9283-7

Claassen M, Zagalo-Pereira G, Soares-Cordeiro AS, Funke N, Nortje K (2019) Research and innovation cooperation in the South Atlantic Ocean. South Afr J Sci 115(9-10):1-2. https://doi.org/10.17159/sajs.2019/6114

Claudet J, Bopp L, Cheung WWL, Devillers R, Escobar-Briones E, Haugan P, .. Gaill F (2019) A roadmap for using the UN decade of ocean science for sustainable development in support of science, policy, and action. One Earth, 2. https://doi.org/10.1016/j.oneear.2019.10.012

Cuyvers L, Berry W, Kristina G, Thiele T, Caroline W (2018) Deep seabed mining: a rising environmental challenge. IUCN and Gallifrey Foundation

deYoung B, Visbeck M, Filho MCA, Baringer MO, Black CA, Buch E, ... Willis Z (2019) An integrated all-Atlantic ocean observing system in 2030. Front Mar Sci, 6. https://doi.org/10.3389/fmars.2019.00428

Dolan BM (2012) Science and technology agreements as tools for science diplomacy: a U.S. case study a formal and legally binding agreement. Science \& Diplomacy, 1(4). Retrieved from http://www.sciencediplomacy.org/article/ 2012/science-and-technology-agreements-tools-for-science-diplomacy

Duarte CM, Agusti S, Barbier E, Britten GL, Castilla JC, Gattuso J-P, Worm B (2020) Rebuilding marine life. Nature 580(7801):39-51. https://doi.org/ 10.1038/s41586-020-2146-7

Duchez A, Frajka-Williams E, Josey SA, Evans DG, Grist JP, Marsh R, ... Hirschi JJM (2016) Drivers of exceptionally cold North Atlantic Ocean temperatures and their link to the 2015 European heat wave. Environ Res Lett, 11(7). https://doi.org/10.1088/1748-9326/11/7/074004

European Commision (2019) The European Green Deal. Communication from the Commission to the European Parliament, the European Council, the Council, the European Economic and Social Committee and the Committee of the Regions $\operatorname{COM(2019)} 640$ Final, p. 24. Retrieved from https://eur-lex.europa. $\mathrm{eu} /$ legal-content/EN/TXT/PDF/?uri=CELEX:52019DC0640\&from $=\mathrm{EN}$

European Commission (2007) An Integrated Maritime Policy for the European Union. Communication from the Commission to the European Parliament, the European Council, the Council, the European Economic and Social Committee and the Committee of the Regions COM(2007) 575 Final, 16. $\operatorname{COM}(2007) 575$ final

European Commission (2011a) Developing a Maritime Strategy for the Atlantic Ocean Area. Communication from the Commission to the European Parliament, the Council, the European Economic and Social Committee and the Committee of the Regions COM(2011) 782 Final, pp. 
1-10. Retrieved from https://eur-lex.europa.eu/legal-content/EN/TXT/ $\mathrm{PDF} /$ ?uri=CELEX:52011DC0782\&from $=\mathrm{EN}$

European Commission (2011b) The Atlantic Geopolitical Space: common opportunities and challenges. Synthesis Report of a Conference Jointly Organised by DG Research and Innovation and BEPA, European Commission. https:// doi.org/10.2777/83581

European Commission (2013) Action plan for a maritime strategy in the atlantic area-delivering smart, sustainable and inclusive growth. Communication from the Commission to the European Parliament, the Council, the European Economic and Social Committee and the Committee of the Regions COM (2013) 279 Final, pp. 1-12. European Commission

European Commission (2017a) All Atlantic Ocean Research Alliance Flagship Funding \& tenders. Retrieved January 28,2020 , from https://ec.europa.eu/info/fundingtenders/opportunities/portal/screen/opportunities/topic-details/bg-08-2018-2019; freeTextSearchKeyword=;typeCodes $=0,1$;statusCodes $=31094501,31094502,3109$ 4503; programCode $=$ null;programDivisionCode $=$ null;focusAreaCode $=$ null;;ros

European Commission (2017b) Sustainable Blue Economy-productive seas and oceans. https://doi.org/10.2777/20162

European Commission (2019) The EU Blue Economy Report. https://doi.org/ $10.2771 / 437478$

European Commission (2020) A new approach to the Atlantic maritime strategy-Atlantic action plan 2.0-An updated action plan for a sustainable, resilient and competitive blue economy in the European Union Atlantic area. In Communication from the Commission to the European Parliament, the Council, the European Economic and Social Committee and the Committee of the Regions $\operatorname{COM}(2020) 329$ final. Retrieved fro006D https://eur-lex. europa.eu/legal-content/EN/ALL/?uri=CELEX:52011DC0782

European Commission, Argentina (2018) Administrative Arrangement on Marine Research and Innovation Cooperation. Retrieved from https://allatlanticocean. org/uploads/ficheiro_Administrative_Arrangement_EC_Argentina_Marine_Rese arch_Innovation_Cooperation.pdf

European Commission, Cabo Verde (2018) Cooperation arrangement on marine research and innovation cooperation. Retrieved from https://allatlanticocean.org/ uploads/ficheiro_Cooperation_Arrangement_EC_Cabo_Verde_Marine_Research Innovation_Cooperation.pdf

European Union (2019) Improving international ocean governance-two years of progress. https://doi.org/10.2771/984360

European Union (2020) The EU Blue Economy Report. https://doi.org/10.2771/ 073370

European Union, Brazil (2015) Joint Declaration of Intent between the European Commission and the Ministry of Science, Technology and innovation of Brazil. Retrieved from https://ec.europa.eu/research/bioeconomy/pdf/declaration_of_int ent.pdf

European Union, Canada, United States of America (2013) The Galway Statement on Atlantic Ocean Cooperation. Retrieved from https://ec.europa.eu/ research/iscp/pdf/galway_statement_atlantic_ocean_cooperation.pdf

European Union, South Africa (2016) Declaration of Intent Between South Africa's Department of Science and Technology and the European Commission on Marine Research and Innovation Co-operation. Retrieved from https://ec. europa.eu/research/iscp/pdf/policy/declaration_of_intent_ec-sa.pdf

European Union, South Africa, Brazil (2017) Belém Statement on Atlantic Research and Innovation Cooperation. Retrieved from https:/ec.europa.eu/ research/iscp/pdf/Belem_statement_2017_en.pdf

Flink T, Rüffin N (2019) The current state of the art of science diplomacy. In: Simon D, Kuhlmann S, Stamm J, Canzler W (eds.) Handbook on Science and Public Policy. pp. 104-121, Edward Elgar Publishing

Flink T, Schreiterer U (2010) Science diplomacy at the intersection of S\&T policies and foreign affairs: toward a typology of national approaches. Sci Public Policy 37(9):665-677. https://doi.org/10.3152/030234210X12778118264530

Food and Agriculture Organization of the United Nations (2020) The State of World Fisheries and Aquaculture 2020. Food and Agriculture Organization of the United Nations. https://doi.org/10.4060/ca9229en

Fritz J-S (2016) Observations, diplomacy, and the future of ocean governance. Science \& Diplomacy, 5(4). Retrieved from http://www.sciencediplomacy. org/article/2016/observations-diplomacy-and-future-ocean-governance

Gluckman PD, Turekian VC, Grimes RW, Kishi T (2018) Science diplomacy: a pragmatic perspective from the inside. Science \& Diplomacy, 6(4 Dec)

Halpern BS, Walbridge S, Selkoe KA, Kappel CV, Micheli F, D’Agrosa C, Watson R (2008) A global map of human impact on marine ecosystems. Science 319 (5865):948-952. https://doi.org/10.1126/science.1149345

Halvorson HO, Quezada, F (2009) Marine biotechnology. In: Steele JH (Ed.), Encyclopedia of Ocean Sciences. (pp. 560-566). Academic Press. https://doi. org/10.1016/B978-012374473-9.00772-4

Inniss L, Simcock Amanuel Yoanes Ajawin A, Alcala AC, Bernal P, Calumpong HP, Eghtesadi Araghi P, ... Marcin Węsławski J (2017) The first global integrated marine assessment (United Nations, ed.). United Nations
IOC-UNESCO (2017) Global Ocean Science Report-The current status of ocean science around the world. In: Valdés L (ed). United Nations Educational, Scientific and Cultural Organization

IOC-UNESCO (2018) Revised roadmap for the UN decade of ocean science for sustainable development. In IOC/EC-LI/2 Annex 3. Retrieved from https:/ oceandecade.org/assets/uploads/documents/EC51-2A3-Roadmap_e_1564761 714.pdf

Körtzinger A, Schimanski J, Send U, Wallace D (2004) The ocean takes a deep breath. Science 306(5700):1337. https://doi.org/10.1126/science.1102557

Lamy P, Citores A, Deidun, A, Evans L, Galgani F, Heffernan P, ... Pons G (2020) Mission Starfish 2030: restore our ocean and waters. In: Independent experts report of the mission board healthy oceans, seas, coastal and inland waters. Publications Office of the European Union. Mission Board Healthy Oceans, Seas, Coastal and Inland Waters members (eds). https://doi.org/10.2777/678915

Levin PS, Fogarty MJ, Murawski SA, Fluharty D (2009) Integrated ecosystem assessments: developing the scientific basis for ecosystem-based management of the ocean. PLoS Biol 7(1):e1000014. https://doi.org/10.1371/journal.pbio.1000014

López de San Román A, Schunz S (2018) Understanding European union science diplomacy. J Common Mark Stud 56(2):247-266. https://doi.org/10.1111/ jcms.12582

Lopez H, Dong S, Lee SK, Goni G (2016) Decadal modulations of interhemispheric global atmospheric circulations and monsoons by the South Atlantic meridional overturning circulation. J Clim 29(5):1831-1851. https://doi.org/ 10.1175/JCLI-D-15-0491.1

Lubchenco J, Gaines SD (2019) A new narrative for the ocean. Science 364 (6444):911. https://doi.org/10.1126/science.aay2241

Lubchenco J, Petes L (2010) The Interconnected biosphere: science at the ocean's tipping points. Oceanography 23(2):115-129. https://doi.org/10.5670/oceanog.2010.55

Mackenzie B, Celliers L, Assad LP, de F, Heymans JJ, Rome N, Thomas J, Terrill E (2019) The role of stakeholders in creating societal value from coastal and ocean observations. Front Mar Sci 6(Mar):137. https://doi.org/10.3389/ fmars.2019.00137

Mazzucato M (2018) Mission-oriented in the European Union. Publications Office of the European Union

Miloslavich P, Bax NJ, Simmons SE, Klein E, Appeltans W, Aburto-Oropeza O, Shin Y-J (2018) Essential ocean variables for global sustained observations of biodiversity and ecosystem changes. Global Chang Biol 24(6):2416-2433. https://doi.org/10.1111/gcb.14108

Miloslavich P, Klein E, Díaz JM, Hernández CE, Bigatti G, Campos L, Martín A (2011) Marine biodiversity in the Atlantic and pacific coasts of South America: knowledge and gaps. PLoS ONE 6(1):e14631. https://doi.org/ 10.1371/journal.pone.0014631

Nieuwejaar P, Mazauric V, Betzler C, Carapuço M, Cattrijsse A, Coren F, ... Naudts L (2019) Next generation European research next generation European research vessels: current status and foreseeable evolution. Position Paper 25 of the European Marine Board. European Marine Board

Pelc R, Fujita RM (2002) Renewable energy from the ocean. Marine Policy. https:// doi.org/10.1016/S0308-597X(02)00045-3

Raineault NA, Flanders J (2019) New frontiers in ocean exploration: the E/V Nautilus, NOAA Ship Okeanos Explorer, and R/V Falkor 2018 field season. Oceanography 32(1 suplement):150. https://doi.org/10.5670/oceanog.2019. supplement.01

Robinson S (2020) Early twentieth-century ocean science diplomacy. Hist Stud Nat Sci 50(4):384-410. https://doi.org/10.1525/hsns.2020.50.4.384

Rockström J, Steffen W, Noone K, Persson Å, Chapin FS, Lambin EF, Foley JA (2009) A safe operating space for humanity. Nature 461(7263):472-475. https://doi.org/10.1038/461472a

Rodríguez Mega, E (2019) Funding crisis at Brazilian science agency could leave 80,000 researchers and students without pay. Science https://doi.org/10.1126/ science.aaz1848

Rüffin N (2020) EU science diplomacy in a contested space of multi-level governance: Ambitions, constraints and options for action. Res Policy 49 (1):103842. https://doi.org/10.1016/j.respol.2019.103842

Ruffini P-B(2020) Conceptualizing science diplomacy in the practitioner-driven literature: a critical review Human Soc Sci Commun 7(1):1-9. https://doi.org/ 10.1057/s41599-020-00609-5

Ryabinin V, Barbière J, Haugan P, Kullenberg G, Smith N, McLean C, ... Rigaud J (2019) The UN decade of ocean science for sustainable development. Front Marine Science, 6(Jul). https://doi.org/10.3389/fmars.2019.00470

Schmidt JO, Bograd SJ, Arrizabalaga H, Azevedo JL, Barbeaux SJ, Barth JA, Zawislak PA (2019) Future ocean observations to connect climate, fisheries and marine ecosystems. Front Mar Sci 6(Sept):550. https://doi.org/10.3389/ fmars.2019.00550

Small C, Nicholls RJ (2003) A global analysis of human settlement in coastal zones. J Coast Res, 19(3), 584-599. Retrieved from https://www.jstor.org/stable/ 4299200 
Smith RD, Maltby E (2003) Using the ecosystem approach to implement the convention on biological diversity: key issues and cases studies. IUCN. https://doi.org/10.2305/IUCN.CH.2003.CEM.2.en

Stenseth NC, Payne MR, Bonsdorff E, Dankel DJ, Durant JM, Anderson LG, ... Paasche $\varnothing$ (2020) Attuning to a changing ocean. Proc Natl Acad Sci, 201915352. https://doi.org/10.1073/pnas.1915352117

Tanhua T, McCurdy A, Fischer A, Appeltans W, Bax N, Currie K, Wilkin J (2019) What we have learned from the framework for ocean observing: evolution of the global ocean observing system. Front Mar Sci 6(Aug):471. https://doi.org/ 10.3389/fmars.2019.00471

The Royal Society, AAAS (2010) New frontiers in science diplomacy. Retrieved from https://royalsociety.org/ /media/Royal_Society_Content/policy/publications/2010 /4294969468.pdf

Todd RE, Chavez FP, Clayton S, Cravatte S, Goes M, Graco M, Zhang L (2019) Global perspectives on observing ocean boundary current systems. Front Mar Sci 6(Jul):423. https://doi.org/10.3389/fmars.2019.00423

Turekian V (2018) The evolution of science diplomacy. Global Policy 9(Nov):5-7. https://doi.org/10.1111/1758-5899.12622

Turekian VC, Copeland D, Davis LS, Patman RG, Pozza M (2015) The emergence of science diplomacy. In: Davis LS, Patman RG (eds), Science diplomacy-new day or false dawn?. 1st edn, pp. 3-24. World Scientific

UNEP (2009) Ecosystem management programme: a new approach to sustainability. UNEP

United Nations (2017) UN Resolution A/RES/72/73. vol. 77. United Nations

Visbeck M (2018) Ocean science research is key for a sustainable future. Nat Commun 9(1):1-4. https://doi.org/10.1038/s41467-018-03158-3

Vogler J (2012) Global commons revisited. Global Policy 3(1):61-71. https://doi. org/10.1111/j.1758-5899.2011.00156.x

Wagner CS (2002) The elusive partnership: science and foreign policy. Sci Public Policy 29(6):409-417. https://doi.org/10.3152/147154302781780741

Wisz MS, Satterthwaite EV, Fudge M, Fischer M, Polejack A, John MS, Rudd MA (2020) 100 opportunities for more inclusive ocean research: cross-disciplinary research questions for sustainable ocean governance and management. Front Mar Sci 7(576):1-23. https://doi.org/10.3389/fmars.2020.00576

\section{Acknowledgements}

The authors thank Ronán Long for the review of the draft manuscript. AP thanks the Global Ocean Institute, from the World Maritime University. AP is supported by the
Swedish Agency for Marine and Water Management-SWAM, and the German Ministry of Transport and Digital Infrastructure through the Land-to-Ocean Leadership Program and by the Brazilian Ministry of Science, Technology and Innovations. This article is delivered under the MISSION ATLANTIC project funded by the European Union's Horizon 2020 Research and Innovation Program under grant agreement No. 639862428 This paper reflects only the authors' views. The European Commission and the Brazilian Ministry of Science, Technology and Innovation are not responsible for any use that may be made of the information it contains.

\section{Competing interests}

The authors declare no competing interests.

\section{Additional information}

Correspondence and requests for materials should be addressed to A.P.

Reprints and permission information is available at http://www.nature.com/reprints

Publisher's note Springer Nature remains neutral with regard to jurisdictional claims in published maps and institutional affiliations.

(c) (i) Open Access This article is licensed under a Creative Commons Attribution 4.0 International License, which permits use, sharing, adaptation, distribution and reproduction in any medium or format, as long as you give appropriate credit to the original author(s) and the source, provide a link to the Creative Commons license, and indicate if changes were made. The images or other third party material in this article are included in the article's Creative Commons license, unless indicated otherwise in a credit line to the material. If material is not included in the article's Creative Commons license and your intended use is not permitted by statutory regulation or exceeds the permitted use, you will need to obtain permission directly from the copyright holder. To view a copy of this license, visit http://creativecommons.org/ licenses/by/4.0/.

(C) The Author(s) 2021 